This is an electronic reprint of the original article. This reprint may differ from the original in pagination and typographic detail.

Author(s): Eloranta, Johanna; Jalkanen, Juha

Title: Learning paths on elementary university courses in Finnish as a second language

Year: $\quad 2015$

Version:

Please cite the original version:

Eloranta, J., \& Jalkanen, J. (2015). Learning paths on elementary university courses in Finnish as a second language. In J. Jalkanen, E. Jokinen, \& P. Taalas (Eds.), Voices of pedagogical development : expanding, enhancing and exploring higher education language learning (pp. 225-240). Research-publishing.net.

https://doi.org/10.14705/rpnet.2015.000294

All material supplied via JYX is protected by copyright and other intellectual property rights, and duplication or sale of all or part of any of the repository collections is not permitted, except that material may be duplicated by you for your research use or educational purposes in electronic or print form. You must obtain permission for any other use. Electronic or print copies may not be offered, whether for sale or otherwise to anyone who is not an authorised user. 


\title{
11 Learning paths on elementary \\ 1 university courses in Finnish \\ as a second language
}

\section{Johanna Eloranta ${ }^{1}$ and Juha Jalkanen ${ }^{2}$}

\section{Abstract}

\begin{abstract}
long with the growing degree of internationalisation, Finnish A university education needs to address issues related to learning and teaching Finnish as a second language. From the perspective of teaching Finnish and related pedagogical development, it is essential to recognise when, where and for which purposes learners need Finnish at the various stages of the language acquisition process. This article focuses on the learning paths of three international students who studied Finnish on a one-term elementary course at the University of Jyväskylä Language Centre. The article is based on a socio-cultural and ecological view on language learning and teaching. The data consist of learning diary texts written by the students during the course. Through these texts, university students' language usage situations and views on the Finnish language and its acquisition are explored. The learners' narratives conveyed their ideas related to languages and language acquisition, which appeared to be central background factors for different language usage and study practices. The three learner paths represented different forms and degrees of integration. The learners' goals were closely related to the environments in which they led their daily lives.
\end{abstract}

Keywords: Finnish, second language learning, higher education, internationalisation, university students, interaction.

\footnotetext{
1. Language Centre, University of Jyväskylä, Finland; johanna.eloranta@jyu.fi

2. Language Centre, University of Jyväskylä, Finland; juha.jalkanen@jyu.fi
}

How to cite this chapter: Eloranta, J., \& Jalkanen, J. (2015). Learning paths on elementary university courses in Finnish as a second language. In J. Jalkanen, E. Jokinen, \& P. Taalas (Eds), Voices of pedagogical development - Expanding, enhancing and exploring higher education language learning (pp. 225-240). Dublin: Research-publishing.net. doi:10.14705/rpnet.2015.000294 


\section{Introduction}

Increasing internationalisation has also challenged Finnish university education to consider questions related to learning and teaching Finnish as a second language (F2). As a result of international recruitment, universities employ a growing number of teaching and research staff for whom learning Finnish is an important channel for integration into the university community and Finnish society. To some extent, the international students enrolled in master's degree programmes and doctoral programmes share similar needs. Many exchange students, who usually spend either one or two terms in Finland, also want and need to learn some Finnish. Matching the diverse needs and goals is one of the key challenges for teaching Finnish as a second language at university today.

From the perspective of teaching Finnish and related pedagogical development, it is essential to recognise when, where and for which purposes learners need Finnish at the various stages of the language acquisition process. Even though there is relatively abundant research on the integration of immigrants into Finnish society, this research has primarily focused on daily and working life contexts (see e.g. Pöyhönen, Rynkänen, Tarnanen \& Hoffman 2013; Suni 2008). The integration of international students into the academic community and the Finnish language community has not been studied from the perspective of learning Finnish. Research into second language (L2) pedagogy, particularly at the university level, has as yet also been scarce in Finland (however, see Aalto \& Taalas 2005 and Jalkanen \& Vaarala 2013).

In this article we explore the learning paths of three international students who studied Finnish on a one-term elementary course at the University of Jyväskylä Language Centre. The focus is on events that are significant for the learning process and on the role of language in them. The following research questions will be answered:

- How do the learners describe their F2 learning paths?

- How do the learners' descriptions portray the Finnish language and learning Finnish? 
First, we present some current research trends in L2 learning, concentrating on a pedagogical viewpoint. Thereafter, we describe the data used in the article as well as the analysis results divided into three sections. Finally, we discuss what the learners' descriptions reveal about university students' initial F2 learning paths and what guidelines the results offer for developing F2 university pedagogy.

\section{Learning $L 2$ in interaction}

Recent research into second-language acquisition highlights that language is learned in interaction, not for it (e.g. Suni 2008). This seemingly small distinction is visible, in particular, in viewing language skills as situational (Dufva \& Aro 2012; Gee 2004; Pennycook 2010). The approach implies that interaction is the starting point for learning, not its terminal point. Practice is still needed, but structures and vocabulary are approached by examining the situations in which they are typically used. The linguistic environment is thus highly significant for the learning process. Teaching should help learners to analyse different interaction situations at school and in their leisure time as well as the surrounding linguistic environment.

Language is today actually regarded as an activity in which linguistic resources are utilised. These resources vary from one situation and modality to the next. This approach basically includes the spatial variation and temporal regeneration of language (Dufva \& Aro 2012). From the language acquisition point of view, this means that language proficiency is not demonstrated as mastery of grammar but as a strategic ability to use different multimodal meaning-making tools in a goal-oriented way (Canagarajah 2008; Pennycook 2010).

Within L2 learning, ground has been particularly gained by holistic theories that aim at explaining the complex and dynamic nature of the language acquisition process. Complexity theory (Larsen-Freeman \& Cameron 2008) and an ecological approach (van Lier 2004) share a systemic approach to 
language acquisition and highlight the need to understand the connections between processes occurring at different levels. Larsen-Freeman and Cameron (2008) also emphasise that it is essential to see language as a dynamic system that is constantly shaped in human interaction. From a pedagogical viewpoint, the idea of dynamic language usage implies that, for example, the discussions recorded in learning materials are always in a certain sense frozen and static. On the other hand, teaching should also provide safe possibilities to test the application of language systems (see also Gee 2005).

Even though teaching plays a central role in L2 acquisition, its primary purpose is to support and structure the learning process rather than to define or control learning sequences based on assumed language difficulty levels (Larsen-Freeman \& Cameron 2008; Suni 2008). By following the learners' progress, pedagogical support can be targeted at different process stages at the right time. This is how the learners' orienteering on their learning paths can be guided toward the next control point, whereby they can structure a part of the linguistic system as a meaningful and intelligible whole (Larsen-Freeman \& Cameron 2008).

\section{The context and data}

Students who attend F2 courses at, for instance, Finnish university language centres have very different backgrounds and starting points. They come from different parts of the world, with different school and learning cultures, and speak different languages. Furthermore, it is typical for these courses that the groups consist of exchange students, international master's degree programme students and postgraduate students. As a consequence of this heterogeneity and differing personal plans and goals, the participants' expectations for their learning outcomes also vary. Exchange students who stay in Finland for four months may be motivated to study Finnish in order to facilitate everyday situations, or some of them are interested in knowing an exotic language. On the other hand, master's degree students who intend to pursue a career and remain permanently in Finland may aim at applying for a job in Finnish within 
a few years. Naturally, in addition to these extreme cases, there are a large number of students with no clear plans and hopes for the future yet. At the initial stage, teaching therefore involves finding a balance between students' diverse interests and learning paths.

The data for this study were collected on an initial F2 course in the autumn of 2014 (target level: CEFR A1 / basic user). Instead of a presumed hierarchical learning sequence, the course was designed based on language usage situations that are meaningful for the learners. A common starting point for initial teaching is the idea of a basic language proficiency that must be acquired before language can be used in interaction. This approach influences learning materials so that the spectrum of texts and language usage situations becomes narrow and irrelevant for the needs of the user. In order to avoid this disadvantage, we mapped the learners' language usage situations via an inquiry before designing the course. The situations chosen for the course included different types of linguistic resources, which the students either analysed or learned to identify. All the situations also entailed linguistic resources that were beyond the learners' comprehension abilities. The aim was to direct their focus to the development of strategic skills and discovery of core content. The course was organised for the first time in its new format while collecting the resources, and the new approach was piloted with one student group.

Students with varying countries of origin, mother tongues and student statuses were selected for the study. The aim was to cast light on learner paths that had different individual starting points. According to these criteria, three participants were chosen: Julie, Naoto and Daniel (the names are pseudonyms).

The research data consist of the learning diaries written by the participants in the course online learning environment. The diary entries were written approximately once a month. The narrative nature of the data links our study to a narrative research approach, which according to Webster and Mertova (2007) is optimally suited for analysing the complex and nuanced experiences that learning and teaching involve. In narrative research, individual experiences are 
recorded through the construction and reconstruction of personal stories, which makes it possible to record and retell events that have been the most influential for participants. Therefore, the narrative approach allows researchers to portray experiences holistically, in all their complexity and richness, trying to illustrate the temporal notion of experience, which is based on the idea that an individual's understanding of people and events changes (Webster \& Mertova 2007).

The objective of narrative analysis is to discover in the data those stories that represent the phenomenon. Narrative analysis yields generalisations about thinking, activity, meanings and attitudes that are related to the phenomenon. In this study, we read the students' learning diaries first alone and then compared our observations and interpretations. Even though the aim in interpreting the diaries was to convey each learner's personal voice, the interpretation involved retelling the stories. The students wrote their diaries in English, and their diverse language skills may have affected the way they verbalised their experiences. The aim was also to take this into account in analysing the texts.

The following sections present the participants' learning paths, first by introducing their backgrounds. The learners' reasons for studying Finnish and set learning outcomes are described thereafter. Then we characterise how language and its learning are manifested in the learners' narratives, as well as potential turning points that appear as meaningful for the learning process. Finally, the focus will be on the learners' retrospective thoughts about learning Finnish. The structure of the descriptions is chronological, that is, they proceed as the course progresses.

\section{Three beginners' learning paths}

\subsection{Path 1: the language enthusiast}

Julie was an exchange student from Central Europe. Her mother tongue was French and her major subject during the six-month exchange period was political science. 
According to Julie, learning Finnish was an essential part of a relatively long stay in Finland. She found that in addition to the practical functions of language, such as going to shops and talking to people, it also opens a window to the Finnish mindset and culture. Moreover, Julie mentioned that for her learning languages was a hobby.

Julie's aim was that after living four months in Finland she would be able to speak Finnish, as she described it, 'at the basic level'. She also wanted to know some Finnish grammar. Julie specified the means of achieving her learning outcomes on a general level by using passive constructions. She regarded the Finnish course as the primary step in learning the language and mentioned daily life language usage situations, such as going to shops and cafes and using public transport, in this context. Julie noted that conversations with native speakers of Finnish were a good way to learn the language, particularly vocabulary. However, she suspected that the language she would learn from Finns would mainly be slang and vulgar vocabulary. Because of the general nature of her description, it was difficult to conclude which of the aforementioned language usage situations Julie intended to utilise in her learning.

As the course progressed, Julie frequently reflected on the differences and similarities between Finnish and the other languages she knew (French, Italian, English and Russian), trying to define her relationship to the structural system of the language. Julie explained that her Russian skills helped her perceive the structures of Finnish, even though she generally found the differences between Finnish and the Indo-European languages challenging. Nonetheless, she remarked that she enjoyed learning a new linguistic system.

Julie seemed to have a relatively structure-oriented approach to Finnish, which was manifested distinctly as a conflict between her interests (verbs, tenses, suffixes) and the situational approach applied in the course (forming questions, asking for directions, agreeing on appointments). In addition to structures, Julie frequently mentioned wanting to expand her vocabulary, yet without specifying the type of vocabulary she needed. She also regarded speaking and writing as individual subareas to be developed separately. 
Julie defined language usage as a game of two levels: on the first level, one learns and uses language in the closed, safe and undisturbed course environment, whereas the second level involves language usage in more challenging contexts characterised by time pressures and external distractions. According to Julie, practising on the first level, that is, in the classroom, prepares students for the second level.

The turning point in Julie's language learning process can be dated to the final stage of the course, at which her language usage environments expanded to meaningful extramural situations. She mentioned reading Moomin books and buying tickets on the internet as examples of these situations. When comparing her achieved learning outcomes to her initial goals, she noted having obtained the keys to speaking and understanding Finnish at the basic level. Julie found that the course had been useful for living in Finland even though its major benefit for her was the opportunity to explore Finnish language and culture, in compliance with her attitude toward languages as a hobby.

\subsection{Path 2: the persistent labourer}

Naoto was an exchange student of biological and environmental science, whose mother tongue was Japanese. He lived in Finland for approximately nine months during his studies.

Naoto told that he chiefly attended the Finnish course in order to master everyday situations, which he described as 'a quiz game'. For example, figuring out the content of food packages and prices in supermarkets presented great challenges to him in spite of contextual clues. Furthermore, he regarded studying Finnish as an opportunity to learn more about Finnish culture.

At the beginning of the course, Naoto's only objectives were knowledge of grammar and fluency of speech. He said that he studied Finnish in order to be able to use it; such simple phrases as yksi kahvi (one coffee) he mentioned having already adopted in his everyday usage. The initial situation for learning Finnish differed from what he had expected: his social network included mainly other 
exchange students. The role of strong emotions was visible in Naoto's attitude toward language acquisition and usage already at an early stage. He found it irritating having to be involved in the daily quiz game, but tried to change his attitude toward the issue.

As the course progressed, Naoto found that he mastered daily language usage situations relatively fluently as long as they did not include excessive variation. However, particularly challenging for him were situations that required finding essential information from texts and deducing meanings. One of the reasons for this, as mentioned by Naoto himself, was the dissimilarity of languages. Naoto's learning targets had been specified at this stage: he highlighted basic vocabulary and, in particular, verbs as the focus of his learning.

The first significant event in Naoto's language acquisition process occurred as he was halfway through the course. He explained how he had tried to make himself understood in Finnish by a cafeteria attendant but had begun to speak English because of time pressure and the other party's problems in understanding. He found that Finns' generally good English skills allow changing the language in challenging situations. Emotions were strongly present in this situation: the attendant's confusion and insecurity made Naoto feel uncomfortable.

A turning point in Naoto's Finnish studies occurred at the final stage of the course. Naoto still highlighted his lexical challenges related to recalling and recognising words. Therefore, reading was difficult for him and a dictionary was constantly needed while writing. He experienced that the texts became increasingly difficult but his reading skills did not develop at the same pace. Naoto also found listening comprehension challenging because he did not understand all he heard and had to guess some meanings. He was ashamed when speaking Finnish. These extremely strong emotions weakened his motivation to study and his willingness to attend the lessons. However, he was not willing to terminate his Finnish studies. According to Naoto, the challenges related to studies resulted from working method differences as well as limited time resources and English skills. 
The next turning point followed right at the end of the course. Naoto explained that he had reflected on his own class participation and noticed that he had avoided interaction with the other students: instead of participating in class, he had only been 'attending' it. According to him, this passiveness had been affected by his incapability of expressing his thoughts fluently, which had posed emotional challenges for him. Nevertheless, supported by a peer and encouraged by positive interaction situations, Naoto's ultimate experience of the course was positive.

\subsection{Path 3: the passionate adventurer}

Daniel was a North American student enrolled in an English-medium master's degree programme in sport sciences at the University of Jyväskylä. Master's degree programmes are usually completed in two to three years. Daniel had just begun his studies in Finland when he came to the F2 course.

Daniel's initial target was to acquire a language proficiency level that would allow him to communicate in ordinary everyday situations and to continue studying Finnish in the future. He defined the target situation also as a personal feeling of being able to say that he knew some Finnish. On the other hand, he also wished to acquire a language proficiency level appreciated by native Finnish speakers. Daniel's attitude to studying Finnish was extremely positive, and he expressed having enjoyed the first classes.

Daniel retained his positive attitude as his studies progressed: learning Finnish was fun, and he was confident that the interconnections between the things learned would become clearer in the course of time. Daniel also told about his willingness to throw himself into new situations based on an experimental approach in order to see what would happen. He believed that the desire to learn, sufficient practice, immersion in the language, and patience would result in achieving the set targets, irrespective of how loud the social networks echoed the impossibility of learning Finnish. In addition to his confidence, Daniel's learning process was supported by his prior linguistics studies and the lexical similarities between Finnish and English. 
On the other hand, Daniel found the differences in pronunciation and particularly in morphological identification to be challenging. Even though he experienced a need to have more practice in all areas, he explained having noticed how much easier speaking Finnish had already become. Halfway through the course, Daniel still emphasised the importance of practising.

The first significant event on Daniel's learning path was an interaction situation in a cafe. The event was significant because of the presence of a native Finnish speaker whom Daniel wanted to impress. Daniel narrated having placed an order in Finnish and having been satisfied with his own performance in a challenging situation. In addition to ordering, Daniel said he had tried to use the everyday phrases he knew in order to create a conversation. The native Finnish speaker occasionally corrected Daniel's pronunciation, which Daniel interpreted as assistance for his attempt to use Finnish. However, Daniel felt uncomfortable and insecure when talking to a native speaker in a particularly significant interaction situation.

The turning point on Daniel's learning path occurred towards the end of the course. Daniel's earlier enthusiasm and positive attitude had disappeared and given way to an attitude that highlighted the importance of practice. Daniel said that he was partly rather satisfied and partly dissatisfied with the development of his language skills. He focused on describing the areas that needed improvement and felt that his insufficient language proficiency resulted from a lack of independent studying and practice.

At the final stage of the course, Daniel analysed his achieved learning outcomes and development targets in various ways. Relying on his linguistics student background, he felt he discerned Finnish as a language system but found situational and idiomatic language usage challenging, in particular, in interaction with native Finnish speakers. Daniel also reflected on his own initial targets in relation to the present situation. He felt he was now able to communicate relatively well in everyday situations as well as being allowed to say that he knew some Finnish. Nevertheless, Daniel did not feel his language skills were good enough to be appreciated by native speakers. He intended 
to enhance his proficiency by speaking Finnish with native speakers and by independently practising grammar and vocabulary (Table 1).

Table 1. Dimensions of learning paths

\begin{tabular}{|l|l|l|l|}
\hline & Starting point & $\begin{array}{l}\text { Experience } \\
\text { in the learner role }\end{array}$ & $\begin{array}{l}\text { Form and degree } \\
\text { of integration }\end{array}$ \\
\hline Julie & $\begin{array}{l}\text { Interest in learning } \\
\text { another language }\end{array}$ & Feels comfortable & $\begin{array}{l}\text { Access to Finnish culture } \\
\text { through cultural products }\end{array}$ \\
\hline Naoto & $\begin{array}{l}\text { Surviving daily } \\
\text { life in Finland }\end{array}$ & Feels anxious & $\begin{array}{l}\text { Integrated into the exchange } \\
\text { student community but only } \\
\text { loosely into the Finnish- } \\
\text { speaking community }\end{array}$ \\
\hline Daniel & $\begin{array}{l}\text { Building } \\
\text { and maintaining } \\
\text { interaction relationships }\end{array}$ & $\begin{array}{l}\text { Enjoys at first but } \\
\text { gets frustrated during } \\
\text { the learning process }\end{array}$ & $\begin{array}{l}\text { Aims at attachment to Finnish } \\
\text { society and wants to establish } \\
\text { social relationships with Finns }\end{array}$ \\
\hline
\end{tabular}

\section{Discussion}

Guided by our two research questions, we have explored in this article three students' descriptions of their paths to learning Finnish. We have focused on how language and language learning were manifested in the learners' texts and what the texts revealed about the learning paths of university students attending elementary Finnish courses.

The learners' narratives conveyed their ideas related to languages and language acquisition, which appeared to be central background factors for different language usage and study practices. Julie's starting point - her interest in learning another language - was demonstrated by the way she observed her learning and further development targets through linguistic structures and vocabulary. She regarded the Finnish course as the principal language learning setting, from which language usage and learning would later expand to interaction outside of the course context. Naoto's point of departure was more closely related to everyday language usage situations, even though for him also language appeared as mastery of structures and vocabulary. Daniel's motivation for learning Finnish was associated with the social function 
of language: language is used for building and maintaining interaction relationships. Daniel experienced practising Finnish as a means to prepare for future interaction situations. In light of these three cases, language is significant primarily because it enables interaction and functioning in Finnish society. Language learning appears as a chiefly individual in-class activity that serves to enable interaction.

The learners' narratives highlighted a variety of emotions involved in the learning process. Julie seemed to enjoy adopting a learner role, in which she felt safe, whereas Naoto felt anxious in the same role and was unable to adjust his emotions to the learning process. Daniel first felt comfortable in the learner role and had an analytical attitude toward his learning-related emotions. However, his understanding attitude began to give way to impatience during the course. One of the reasons for deciding to use learning diaries in the course was actually our aim to observe the learners' attitudes and emotions during the learning process. Participants often reflected on their experiences more openly in the diaries than in the group sessions. Moreover, the opportunity to concentrate on listening to the experiences of individual learners allowed us to provide targeted feedback on the learning process as well as on linguistic questions.

The three learner paths represented different forms and degrees of integration. Naoto identified the exchange student community as his main social setting. Daniel's aim was attachment to Finnish society, which was demonstrated by his plans to continue studying Finnish and establish social relationships with Finns. Julie, instead, wished to access Finnish culture chiefly through cultural products, not so much through social interaction.

The students' narratives about their learning paths can be crystallised in two key questions: why and how is language learned. The learners' goals were closely related to the environments in which they led their daily lives, yet they focused on different aspects within these environments. From a pedagogical viewpoint, it is challenging to reconcile the diverse goals of language acquisition and social integration. This makes us consider whether it is, overall, meaningful to pursue the goals of these student groups within the framework of one single course. 
The idea of learning in interaction currently prevailing in research on L2 acquisition was not visible in our students' notions (see Partanen 2013). This may partly result from Finns not being used to speaking Finnish with non-native speakers and supporting their initially insecure language usage. In addition, the learners may have lacked the ability to utilise interaction situations as learning situations. Based on our data, however, encounters with native Finnish speakers seem to be significant for the learners of Finnish. Their experiences of genuine interaction situations also seem to have an impact on their conceptions of themselves as language users. In this light, learning a second language in interaction implies throwing ourselves collaboratively into a discomfort zone: native Finnish speakers should recognise their role as support providers and the learners of Finnish as utilisers of this support. Neither of these skills emerges spontaneously but requires conscious and systematic development (on the forms of pedagogical support, see van Lier 2007) This is a challenge that should be addressed in developing pedagogies for both Finnish as a second language and Finnish as mother tongue. Questions related to the contexts in which different language registers are learned must be constantly and actively discussed at the various stages of teaching and learning. The purpose of teaching is also to shape students' conceptions of learning, not only to echo them.

\section{Acknowledgement}

This article has been translated from Finnish by Sirpa Vehviläinen.

\section{References}

Aalto, E. \& Taalas, P. 2005. Tavoitteelliseksi opiskelijaksi monimuotoisella ja -mediaisella kurssilla. In L. Kuure, E. Kärkkäinen, M. Saarenkunnas (eds.), Kieli ja sosiaalinen toiminta - Language and Social Action. AFinLA Yearbook. Publications de l'association finlandaise de linquistique appliquée 63, 349-362. 
Canagarajah, A. S. 2008. Foreword. In A. Clemente \& M. Higgins (eds.), Performing English with a post-colonial accent: ethnographic narratives from Mexico. London: The Tufnell Press, 9-13.

Dufva, H. \& Aro, M. 2012. Oppimisen kronotooppisuus: aika, paikka ja kielenkäyttäjä. In L. Meriläinen, L. Kolehmainen \& T. Nieminen (eds.) AFinLA-e: soveltavan kielitieteen tutkimuksia 4. Jyväskylä: AFinLA, 7-21.

Gee, J. P. 2004. Situated language and learning: a critique of traditional schooling. New York: Routledge.

Gee, J. P. 2005. Learning by design: good video games as learning machines. E-Learning, 2 (1), 5-16. doi:10.2304/elea.2005.2.1.5

Jalkanen, J. \& Vaarala, H. 2013. Digital texts for learning Finnish: shared resources and emerging practices. Language Learning \& Technology, 17 (1), 107-124.

Larsen-Freeman, D. \& Cameron, L. 2008. Complex systems and applied linguistics. Oxford: Oxford University Press.

Partanen, M. 2013. Kieli tulee kielen pällle: kansainvälisten opiskelijoiden käsityksiä suomen kielen oppimisesta. In M. Eronen \& M. Rodi-Risberg (eds.), Haasteena näkökulma, Perspektivet som utmaning, Point of view as challenge, Perspektivität als Herausforderung. Vaasa: VAKKI Publications 2, 257-268.

Pennycook, A. 2010. Language as a local practice. New York: Routledge.

Pöyhönen, S., Rynkänen, T., Tarnanen, M. \& Hoffman, D. 2013. Venäjänkiliset IT-alan asiantuntijat työyhteisöissä - monikieliset käytänteet, identiteetit ja osallisuuden kokemukset integroitumisessa. In T. Keisanen, E. Kärkkäinen, M. Rauniomaa, P. Siitonen \& M. Siromaa (eds.), Osallistumisen multimodaaliset diskurssit. Multimodal discourses of participation. Jyväskylä: AFinLAn vuosikirja. Suomen soveltavan kielitieteen yhdistyksen julkaisuja, 77-102.

Suni, M. 2008. Toista kieltä vuorovaikutuksessa. Kielellisten resurssien jakaminen toisen kielen omaksumisen alkuvaiheessa [Second language in interaction: sharing linguistic resources in the early stage of second language acquisition]. Jyväskylä: Doctoral dissertation, University of Jyväskylä. Retrieved from http://urn.fi/URN:ISBN:978-951-39-3209-1

van Lier, L. 2004. The ecology and semiotics of language learning: a sociocultural perspective. Boston: Kluwer Academic. doi:10.1007/1-4020-7912-5

van Lier, L. 2007. Action-based teaching, autonomy and identity. Innovation in Language. Learning and Teaching, 1(1), 46-65. 
Chapter 11

Webster, L. \& Mertova, P. 2007. Using narrative inquiry as a research method: an introduction to using critical event narrative analysis in research on learning and teaching. London: Routledge. 


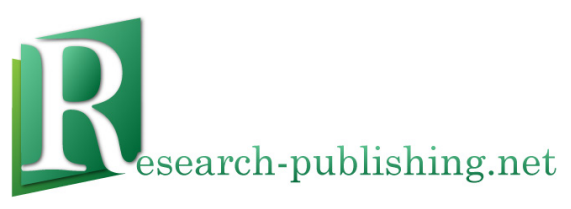

Published by Research-publishing.net, not-for-profit association Dublin, Ireland; Voillans, France, info@research-publishing.net

(C) 2015 by Research-publishing.net (collective work)

Each author retains their own copyright

Voices of pedagogical development - Expanding, enhancing and exploring higher education language learning Edited by Juha Jalkanen, Elina Jokinen, \& Peppi Taalas

Rights: All articles in this collection are published under the Attribution-NonCommercial -NoDerivatives 4.0 International (CC BY-NC-ND 4.0) licence. Under this licence, the contents are freely available online (as PDF files) for anybody to read, download, copy, and redistribute provided that the author(s), editorial team, and publisher are properly cited. Commercial use and derivative works are, however, not permitted.

\section{()ㅛ $\Theta \Theta$}

Disclaimer: Research-publishing.net does not take any responsibility for the content of the pages written by the authors of this book. The authors have recognised that the work described was not published before, or that it is not under consideration for publication elsewhere. While the information in this book are believed to be true and accurate on the date of its going to press, neither the editorial team, nor the publisher can accept any legal responsibility for any errors or omissions that may be made. The publisher makes no warranty, expressed or implied, with respect to the material contained herein. While Research-publishing.net is committed to publishing works of integrity, the words are the authors' alone.

Trademark notice: Product or corporate names may be trademarks or registered trademarks, and are used only for identification and explanation without intent to infringe.

Copyrighted material: Every effort has been made by the editorial team to trace copyright holders and to obtain their permission for the use of copyrighted material in this book. In the event of errors or omissions, please notify the publisher of any corrections that will need to be incorporated in future editions of this book.

Typeset by Research-publishing.net

Cover design by (C) Antti Myöhänen

ISBN13: 978-1-908416-25-4 (Paperback - Print on demand, black and white)

Print on demand technology is a high-quality, innovative and ecological printing method, with which the book is never 'out of stock' or 'out of print'.

ISBN13: 978-1-908416-26-1 (Ebook, PDF, colour)

ISBN13: 978-1-908416-27-8 (Ebook, EPUB, colour)

Legal deposit, Ireland: The National Library of Ireland, The Library of Trinity College, The Library of the University of Limerick, The Library of Dublin City University, The Library of NUI Cork, The Library of NUI Maynooth, The Library of University College Dublin, The Library of NUI Galway.

Legal deposit, United Kingdom: The British Library.

British Library Cataloguing-in-Publication Data.

A cataloguing record for this book is available from the British Library.

Legal deposit, France: Bibliothèque Nationale de France - Dépôt légal: septembre 2015. 